PROC. OF JSCE

No. 339, November 1983

\title{
A STUDY ON LATERAL BUCKLING STRENGTH AND DESIGN AID FOR HORIZONTALLY CURVED I-GIRDER BRIDGES
}

\author{
By Hiroshi NAKAI* and Hisao KOTOGUCHI**
}

\section{INTRODUCTION}

During the past decade, numerous horizontally multiple curved I-girder bridges have been constructed in the highways of all over the world as pointed out in reference ${ }^{1)}$, because such types of bridges can easily be designed and fabricated in the case where the span length of a bridge is comparatively short. For example, it is recommended by the bridge structural design code of the Hanshin Highway Public Corporation ${ }^{2}$ that multiple curved I-girder bridges should be decided in accordance with their radius of curvature $R$ and span length $L$ as shown in Fig. 1 through the various parametric studies.

However, the Japanese Specification for Highway Bridges does not provide a criterion for the lateral buckling strength of the horizontally

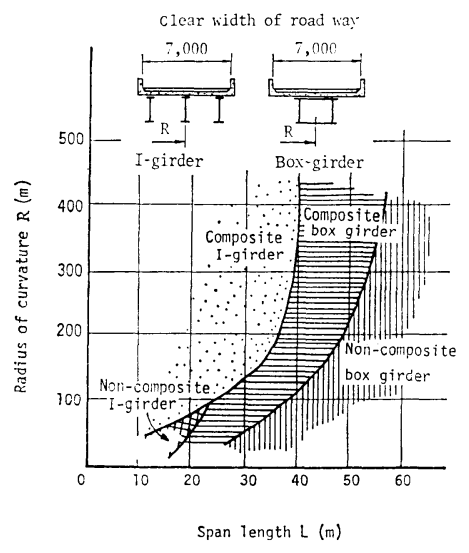

Fig. 1 Adequate type of horizontally curved girder bridges.

* Member of JSCE, Dr. Eng., Professor, Department of Civil Engg., Osaka City University

** Member of JSCE, Dr. Fng., Associate Professor, Department of Construction Engg., Daido Institute of Technology curved I-girder which is adopted as the main girder of the multiple curved I-girder bridges ${ }^{3}$. Therefore, the engineers are always compelled to utilize the criterion for that of the straight girder bridges. There are, accordingly, so many unclarified problems concerning the safety against the lateral buckling strength of a curved I-girder, that it is an important problem to inquire these points extensively.

This paper deals with the experimental and theoretical studies on the lateral buckling behaviours for the curved I-girders, and gives a recommendation to estimate the lateral buckling strength and apply to a rational design for the multiple curved I-girder bridges.

\section{EXPERIMENTS ON LATERAL BUCKL- ING OF MULTIPLE CURVED I-GIRDER BRIDGES}

The lateral buckling behaviours of multiple curved I-girder bridge will distinctly be classified into two categories as follows, i.e. one is the most dangerous phenomenon such as the overall lateral buckling throughout a bridge, and the other is a local one of the main girders between the supporting points alike the floor beams or sway and lateral bracings. In order to clarify these phenomena, a series of experimental studies were conducted prior to the theoretical analyses.

(1) Overall lateral buckling tests of multiple curved I-girder bridges ${ }^{4}$ )

a) Model girders

Three model girder bridges MG-1, MG-2 and MG-3 with two main I-girders having floor beams and three different lateral bracings were built on the scale $1: 3.8$ based on the dimensional analysis of the actual bridges of the multiple curved I-girder bridges.

Fig. 2 and Fig. 3 show the plan and the crosssection of model girders, respectively. The ratio between span length $L$ and girder spacing $B$ was equal to $L / B=5.56$. The local buckling of flange 


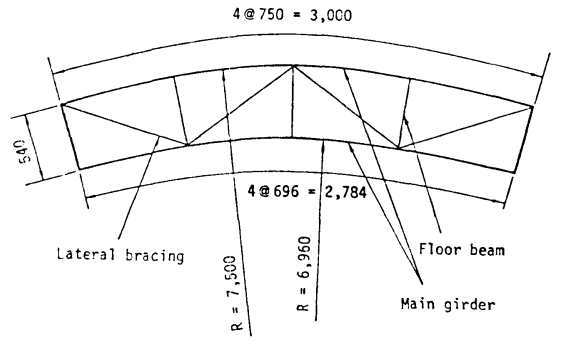

Fig. 2 Plan of model girder (dimension in $\mathrm{nm}$ ).

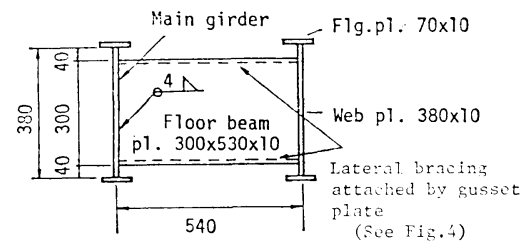

Fig. 3 Cross-section of model girder (dimension in $\mathrm{mm}$ ).

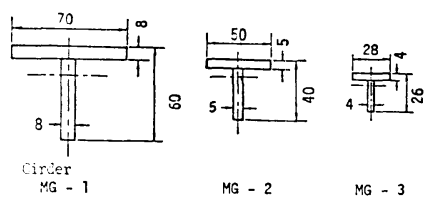

Fig. 4 Cross-section of lateral bracings (dimension in $\mathrm{mm})$.

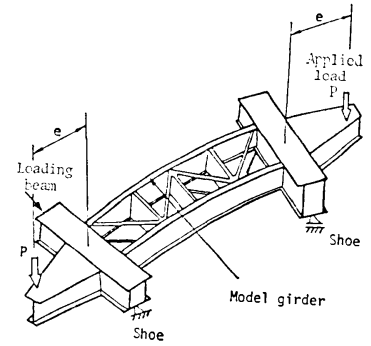

Fig. 5 Loading conditions.

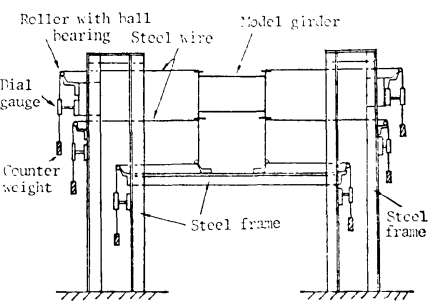

Fig. 6 Measurement of displacements. and web plates could effectively be prevented by taking their thickness as large as possible.

While, the cross-sections of the lateral bracings of the model girders MG-1, MG-2 and MG-3 were respectively chosen to have twice, one and half times of the cross-sectional area of lateral bracings based upon the dimensional analysis of the actual bridges as shown in Fig. 4.

The materials of all these members were made of structural steel SS-41 with the Young's modulus of elasticity $E=2.1 \times 10^{6} \mathrm{~kg} / \mathrm{cm}^{2}(205.8 \mathrm{GPa})$, Poisson's ratio $\mu=0.3$ and yield stress $\sigma_{y}=3100$ $\mathrm{kg} / \mathrm{cm}^{2}$ (303.8 MPa).

\section{b) Loading conditions}

It is preferable that the lateral buckling tests should be performed under a condition where the shearing force will not appear as same as pure bending in a straight beam. To satisfy this condition as exactly as possible, two loading beams with cantilever tongues were bolted to the model girder. The upper shoes using the load cell tranceducers were also bolted to these loading beams and the lower shoes were set in order that the model girder was supported on a roller at one end and a pin at the other. And then the same loads $P$ were applied to the ends of cantilevers by the oil jacks as is seen in Fig. 5 .

Thus, the model girder can approximately be subjected to the pure bending moment $M=$ $P \cdot e$, where $e$ is the eccentricity of the load and the shoe in the direction of the girder axis.

c) Measurements of displacement and strain

The lateral displacements were measured by the special instruments which consist of steel wire $(\phi=0.3 \mathrm{~mm})$, roller with ball bearing, counter weight (300 gr) and dial gauges with the accuracy $1 / 100 \mathrm{~mm}$ as illustrated in Fig. 6 .

On the other hand, strains in main girders and lateral bracings were measured by the ordinary electrical wire strain gauges with the gauge length $5 \mathrm{~mm}$ and $3 \mathrm{~mm}$ for main girder and lateral bracings, respectively.

d) Test results

Fig. 7 shows an example of the load-strain curves for the main girders. The corresponding lateral displacements of the main girders can be plotted as shown in Fig. 8.

Observing Fig. 7, it is clear that the strain at the point 1 in the cross-section changes from compression to tension when the applied moment reaches a certain value. This bending moment can be considered as lateral buckling moment. And, this moment can be decided by obtaining

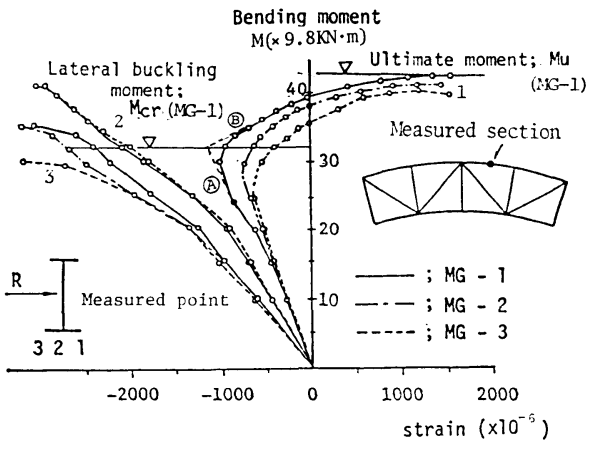

Fig. 7 Load-strain curves (main girder). 


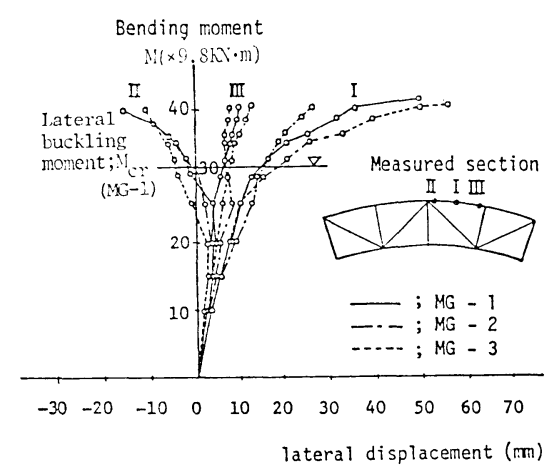

Fig. 8 Load-lateral displacement curves (main girder).

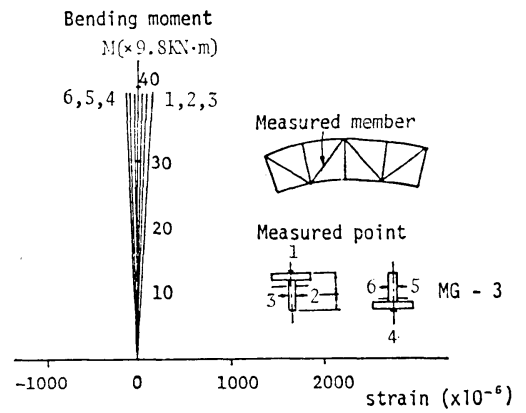

Fig. 9 Load-strain curves (Lateral bracing).

an intersection of the tangents to the load-strain curve at the two points $A$ and $B$ as shown in Fig. 7. Thus, the lateral buckling moments $M$ or and the ultimate moments $M_{u}$ of girders MG-1 through MG-3 can clearly be obtained and these values can be summarized as shown in Table 1 .

Table $1 M_{c r}$ and $M_{u}$ (Unit: $\left.\mathrm{KN} \cdot \mathrm{m}\right)$.

\begin{tabular}{c|c|c}
\hline Girder & $M_{c r}$ & $M_{u}$ \\
\hline MG-1 & 303.8 & 416.5 \\
MG-2 & 294.0 & 401.8 \\
MG-3 & 284.2 & 392.0 \\
\hline
\end{tabular}

From this table, it seems that both the moments $M_{o r}$ and $M_{u}$ are not significantly affected by the differences of the lateral bracings, because the strains remain within the elastic ranges even in a case of the minimum cross-sectional area as shown in Fig. 9.

The relative lateral buckling displacements at the compression flanges of outer girder of MG-3 for each load steps can be plotted as shown in Fig. 10 by the subtraction of the absolute displacements at the junction points of floor beams and lateral bracings. Observing this figure, the

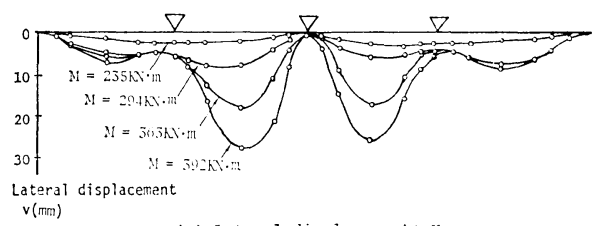

(a) Lateral displacement; v

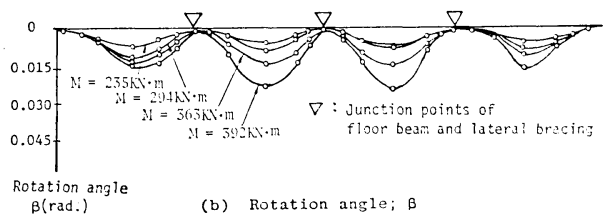

Fig. 10 Lateral buckling modes of outer girder of MG-3.

local lateral buckling modes of the main girder between floor beams and lateral bracings predominate rather than the overall buckling.

In consequence, it is concluded from these facts that the overall lateral buckling of the multiple curved I-girder bridges is not so an important phenomenon that we have to devote our attentions to the local buckling of main girder between the supported portions by floor beams or sway and lateral bracings, if the ratio $L / B$ of span length to girder spacing has a small value, and the floor beams or sway and lateral bracings are designed to have enough strength and rigidity against the lateral loads as described in the preceding section.

\section{(2) Local buckling tests of curved I-girders ${ }^{5)}$}

The buckling tests for a supported portion of the main girders among the junction points of floor beams and lateral bracings, which is idealized as shown in Fig. 11, were undertaken by the similar procedures as mentioned in the above to evaluate the local buckling strength of the main girder. Twenty-seven model girders IG-1 through IG-27 (see Table 2) were tested under the loading conditions as illustrated in Fig. 12.

Typical load-displacement curves and the lateral buckling modes can be plotted as shown in Fig. 13 and Fig. 14, respectively.

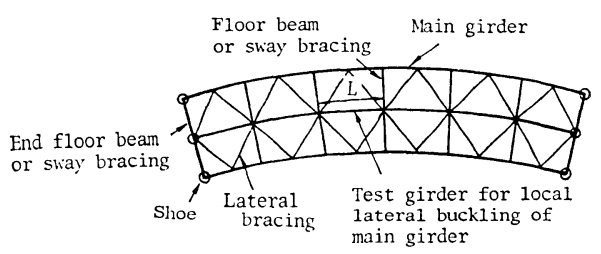

Fig. 11 Detail of multiple curved I-girder bridge. 
Table 2 Comparison of ultimate moment $M_{u}$.

\begin{tabular}{|c|c|c|c|c|c|c|c|c|}
\hline \multirow{2}{*}{ Item } & \multirow{2}{*}{$\begin{array}{l}\text { Span } \\
L(\mathrm{~m})\end{array}$} & \multirow{2}{*}{$\begin{array}{l}\text { Radius } \\
R,(\mathrm{~m})\end{array}$} & \multirow{2}{*}{$\begin{array}{l}\text { Central } \\
\text { angle } \\
\text { (rad.) }\end{array}$} & \multirow{2}{*}{$\begin{array}{c}\text { Flange } \\
\text { area } \\
A_{f}\left(\mathrm{~cm}^{2}\right)\end{array}$} & \multirow{2}{*}{$\begin{array}{c}\text { Web } \\
\text { area } \\
A_{w}\left(\mathrm{~cm}^{2}\right)\end{array}$} & \multicolumn{2}{|c|}{$\begin{array}{c}\text { Ultimate moment } \\
M_{u}(\mathrm{kN}, \mathrm{m})\end{array}$} & \multirow{2}{*}{ Ex./Th. } \\
\hline & & & & & & Ex. & Th. & \\
\hline $\begin{array}{l}1 G-1 \\
1 ;-2 \\
1 G-2 \\
1 G-3\end{array}$ & $\begin{array}{l}2.5 \\
2.5 \\
2.5\end{array}$ & $\begin{array}{r}5 \\
15 \\
30\end{array}$ & $\begin{array}{l}0.5 \\
0.17 \\
0.08\end{array}$ & $\begin{array}{l}8 \\
8 \\
8\end{array}$ & $\begin{array}{l}38 \\
38 \\
38\end{array}$ & $\begin{array}{r}52.9 \\
86.2 \\
109.8\end{array}$ & $\begin{array}{r}58.8 \\
91.1 \\
113.7\end{array}$ & $\begin{array}{l}0.90 \\
0.95 \\
0.97\end{array}$ \\
\hline $\begin{array}{l}\text { IG-4 } \\
\text { IG-5 } \\
\text { IG }-6\end{array}$ & $\begin{array}{l}2.3 \\
2.3 \\
2.3\end{array}$ & $\begin{array}{r}4.6 \\
13.8 \\
27.6 \\
\end{array}$ & $\begin{array}{l}0.5 \\
0.17 \\
0.08\end{array}$ & $\begin{array}{l}18 \\
18 \\
18\end{array}$ & $\begin{array}{l}38 \\
38 \\
38\end{array}$ & $\begin{array}{l}135.2 \\
202.9 \\
202.9\end{array}$ & $\begin{array}{l}178.4 \\
209.8 \\
223.4\end{array}$ & $\begin{array}{l}0.76 \\
0.97 \\
0.91\end{array}$ \\
\hline $\begin{array}{l}\text { IG-7 } \\
\text { IG-8 } \\
\text { IG-9 }\end{array}$ & $\begin{array}{l}1.8 \\
1.8 \\
1.8\end{array}$ & $\begin{array}{r}3.6 \\
10.8 \\
21.6 \\
\end{array}$ & $\begin{array}{l}0.5 \\
0.17 \\
0.08\end{array}$ & $\begin{array}{l}20 \\
20 \\
20\end{array}$ & $\begin{array}{l}38 \\
38 \\
38\end{array}$ & $\begin{array}{l}161.7 \\
261.7 \\
274.4\end{array}$ & $\begin{array}{l}192.1 \\
256.8 \\
263.6\end{array}$ & $\begin{array}{l}0.84 \\
1.02 \\
1.04\end{array}$ \\
\hline $\begin{array}{l}\mathrm{IG}-10 \\
1 \mathrm{IG}-11 \\
1 \mathrm{G}-12 \\
\end{array}$ & $\begin{array}{l}0.9 \\
0.9 \\
0.9 \\
\end{array}$ & $\begin{array}{r}1.8 \\
5.4 \\
10.8 \\
\end{array}$ & $\begin{array}{l}0.5 \\
0.17 \\
0.08 \\
\end{array}$ & $\begin{array}{l}20 \\
20 \\
20\end{array}$ & $\begin{array}{l}38 \\
38 \\
38 \\
\end{array}$ & $\begin{array}{l}201.9 \\
271.5 \\
301.8 \\
\end{array}$ & $\begin{array}{l}251.9 \\
280.3 \\
314.6 \\
\end{array}$ & $\begin{array}{l}0.80 \\
0.97 \\
0.97 \\
\end{array}$ \\
\hline $\begin{array}{l}1 G-13 \\
1 G-14 \\
1 G-15\end{array}$ & $\begin{array}{l}2.5 \\
2.5 \\
2.5 \\
\end{array}$ & $\begin{array}{r}5 \\
15 \\
30 \\
\end{array}$ & $\begin{array}{l}0.5 \\
0.17 \\
0.08 \\
\end{array}$ & $\begin{array}{l}6 \\
6 \\
6 \\
\end{array}$ & $\begin{array}{l}38 \\
38 \\
38 \\
\end{array}$ & $\begin{array}{l}45,1 \\
65,7 \\
80.4 \\
\end{array}$ & $\begin{array}{l}35.3 \\
66.6 \\
80.4\end{array}$ & $\begin{array}{l}1.28 \\
0.99 \\
1.00\end{array}$ \\
\hline $\begin{array}{l}\text { IG-16 } \\
\text { IG-17 } \\
\text { IG-18 }\end{array}$ & $\begin{array}{l}2.5 \\
2.5 \\
2.5 \\
\end{array}$ & $\begin{array}{r}5 \\
15 \\
30 \\
\end{array}$ & $\begin{array}{l}0.5 \\
0.17 \\
0.08 \\
\end{array}$ & $\begin{array}{l}10 \\
10 \\
10 \\
\end{array}$ & $\begin{array}{l}38 \\
38 \\
33 \\
\end{array}$ & $\begin{array}{r}61.7 \\
113.7 \\
136.2 \\
\end{array}$ & $\begin{array}{r}89.2 \\
109.8 \\
120.5 \\
\end{array}$ & $\begin{array}{l}0.69 \\
1.04 \\
1.13 \\
\end{array}$ \\
\hline $\begin{array}{l}1 G-19 \\
1 G-20 \\
I G-21\end{array}$ & $\begin{array}{l}2.5 \\
2.5 \\
2.5\end{array}$ & $\begin{array}{r}5 \\
15 \\
30\end{array}$ & $\begin{array}{l}0.5 \\
0.17 \\
0.08\end{array}$ & $\begin{array}{l}12 \\
12 \\
12\end{array}$ & $\begin{array}{l}38 \\
38 \\
38\end{array}$ & $\begin{array}{r}76.4 \\
139.2 \\
176.4\end{array}$ & $\begin{array}{l}115.6 \\
135.2 \\
150.9\end{array}$ & $\begin{array}{l}0.66 \\
1.03 \\
1.17\end{array}$ \\
\hline $\begin{array}{l}\text { IG }-22 \\
\text { IG }-23\end{array}$ & $\begin{array}{l}2.5 \\
2.5 \\
\end{array}$ & $\begin{array}{l}15 \\
30 \\
\end{array}$ & $\begin{array}{l}0.17 \\
0.08 \\
\end{array}$ & $\begin{array}{l}14 \\
14 \\
\end{array}$ & $\begin{array}{l}38 \\
38 \\
\end{array}$ & $\begin{array}{l}117.4 \\
193.1\end{array}$ & $\begin{array}{l}156.8 \\
162.7 \\
\end{array}$ & $\begin{array}{l}1.13 \\
1.19 \\
\end{array}$ \\
\hline $\begin{array}{l}\text { IG }-24 \\
\text { IG }-25 \\
\text { IG }-26 \\
\text { IG }-27\end{array}$ & $\begin{array}{l}2.3 \\
2.3 \\
2.3 \\
2.3\end{array}$ & $\begin{array}{l}4.6 \\
13.8 \\
27.6 \\
\infty\end{array}$ & $\begin{array}{l}0.5 \\
0.17 \\
0.08 \\
0\end{array}$ & $\begin{array}{l}7 \\
7 \\
7 \\
7\end{array}$ & $\begin{array}{l}38 \\
38 \\
38 \\
38\end{array}$ & $\begin{array}{r}51.0 \\
80.4 \\
100.9 \\
146.0\end{array}$ & $\begin{array}{r}56.8 \\
79.4 \\
91.1 \\
113.7\end{array}$ & $\begin{array}{l}0.90 \\
1.01 \\
1.11 \\
1.28\end{array}$ \\
\hline
\end{tabular}

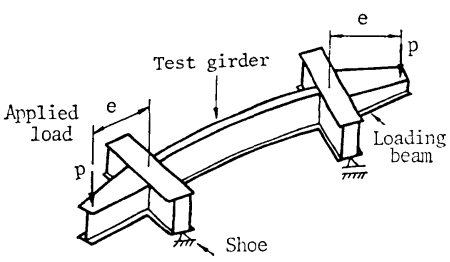

Fig. 12 Loading conditions.

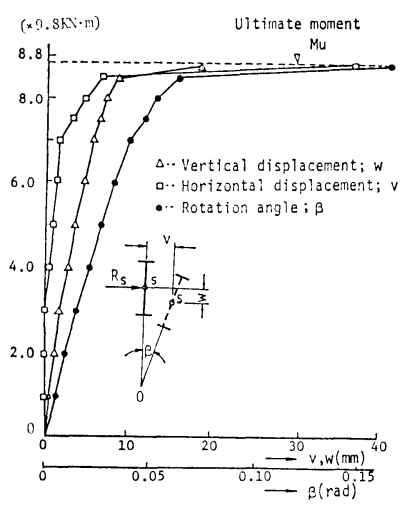

Fig. 13 Load-displacement curves (IG-2).
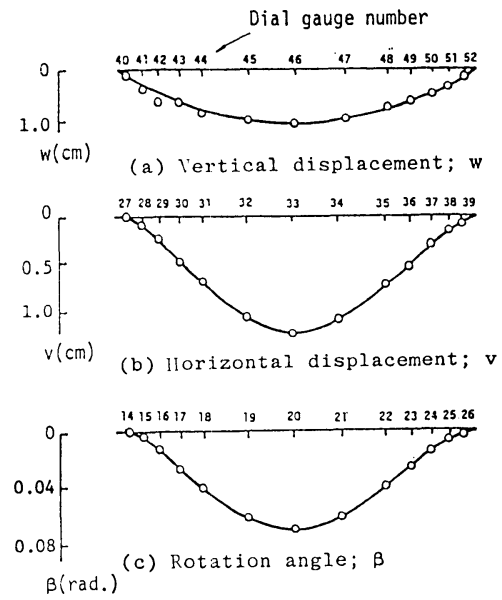

Fig. 14 Buckling modes (IG-2).

\section{ANALYTICAL STUDY ON LATERAL BUCKLING OF CURVED I-GIRDERS}

\section{(1) Analytical study}

The horizontal and vertical displacements and rotation angle of a curved I-beam will occure in a beam even though the applied moment is relatively small. However, once a certain critical moment is reached, the curved beam bows largely out sideways. This bending gives the large displacements which cause a curved I-beam to buckle. A few finite displacement theories, which have been developed by many researchers, ${ }^{6) \sim 13}$ ) can be used to investigate these complex phenomenon.
However, the material non-linearity will predominate greater than the geometrical one. This tendency can obviously be understood by a survey of the actual curved bridges as shown in Fig. 15 $^{14)}$, and almost all the lateral buckling of I-girders fall within the elasto-plastic regions since the buckling parameters (cf. Eq. (13)) have $\alpha=0.3 \sim 1.2^{3)}$.

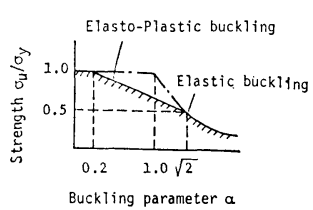

(a) Definition of $\alpha$

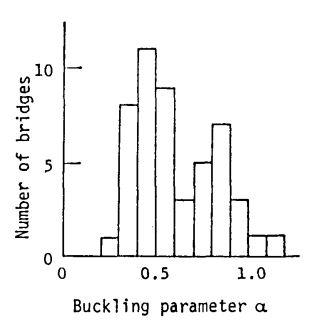

(b) Histogram of $\alpha$
Fig. 15 Lateral buckling parameter $\alpha$ and corresponding buckling behaviours.

Accordingly, this paper deals with the lateral buckling behaviour by the theory based upon second order analysis as pointed out by reference ${ }^{15) \sim 17)}$.

For this analysis, if the buckling displacements at the state- 2 are assumed in reference to the undeformed state-1 in which the displacements in a beam are assumed to be negligible small until the applied moment reaches a lateral buckl- 


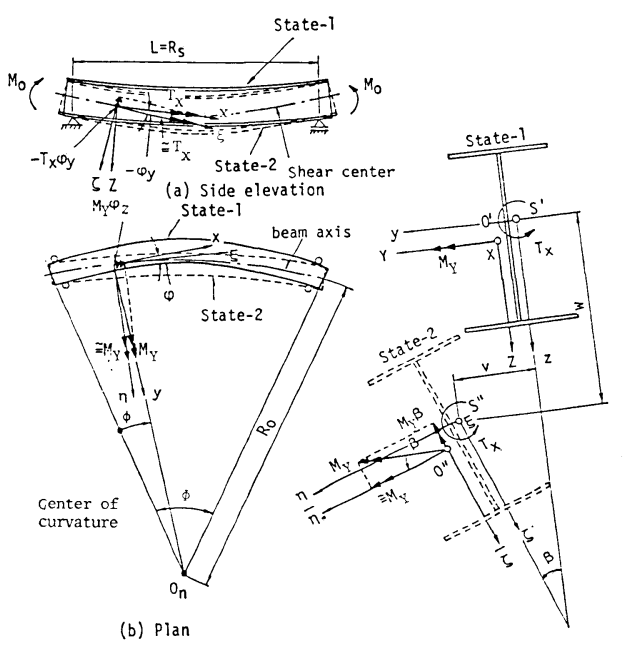

(c) Cross-section

Fig. 16 Buckling displacements and additional stress-resultants.

ing moment, the following relationships between displacements and stress-resultants will be obtained by referring Fig. 16 with an asymmetrical I-girder ${ }^{24)}$;

$$
\begin{aligned}
& E I_{Y}\left(\frac{d^{2} w}{d s^{2}}-\frac{\beta}{R_{s}}\right)+E I_{Y Z}\left(\frac{d^{2} v}{d s^{2}}+\frac{1}{R_{s}} \frac{d u}{d s}\right)=-\frac{R_{0}}{R_{s}} M_{\bar{\eta}} \\
& E I_{Z}\left(\frac{d^{2} v}{d s^{2}}+\frac{1}{R_{s}} \frac{d u}{d s}\right)+E I_{Y Z}\left(\frac{d^{2} w}{d s^{2}}-\frac{\beta}{R_{s}}\right)=\frac{R_{0}}{R_{s}} M_{\bar{\xi}} \\
& E A_{X}\left\{\frac{d u}{d s}-\frac{v}{R_{s}}-\left(\frac{d^{2} w}{d s^{2}}-\frac{\beta}{R_{s}}\right) z_{s}\right. \\
& \left.\quad-\left(\frac{d^{2} v}{d s^{2}}+\frac{1}{R_{s}} \frac{d u}{d s}\right) y_{s}\right\}=\frac{R_{0}}{R_{s}} N_{\bar{\xi}} \\
& E I_{\omega} \frac{d^{2} \theta}{d s^{2}}-\overline{G K} \frac{d \theta}{d s}=-T_{\xi}
\end{aligned}
$$

where

$s$; curvilinear coordinate at shear center

$x, y, z$; axial, horizontal and vertical coordinate axes at shear center

$u, v, w$; displacement in the direction of coordinate axes $(x, y, z)$

$\theta=\beta+w / R_{s} ;$ torsional angle

$\beta$; rotational angle

$E I_{Y}, E I_{Z}, E I_{Y Z}$; flexural rigidity with respect to centroidal axes $Y, Z$, and $Y Z$

$E A_{X}$; elongation rigidity

$E I_{\omega}$; warping rigidity

$$
\overline{G K} ; G K+\int_{A}\left(y^{2}+z^{2}\right) \sigma d A
$$

in which

$G K$; torsional rigidity

$\int_{A}\left(y^{2}+z^{2}\right) \sigma d A$; additional torsional rigidity due to the normal stress $\sigma^{21)}$
$R_{0}, R_{s}$; radius of curvature at centroid $O^{\prime}$ and shear center $S^{\prime}$

$y_{s}, z_{s}$; eccentricity between $O^{\prime}$ and $S^{\prime}$ in the direction of coordinate axes $(y, z)$

Now, the additional stress-resultants in the right-hand side of Eq. (1) at state-2 through state1 will be written as follows;

$$
\left.\begin{array}{l}
N_{\bar{\xi}}=0, \quad M_{\bar{\eta}}=-T_{x^{0}} \varphi_{z} \\
M_{\bar{\zeta}}=-M_{Y^{0}} \beta+T_{x^{0}} \varphi_{y}, \quad T_{\xi}=M_{Y^{0}} \varphi_{z}
\end{array}\right\} \cdots(4)_{\mathrm{a} \sim \mathrm{d}}
$$

When girders undergo only the bending moments around the strong axis at the ends of girder $\phi=0$ and $\phi=\Phi$, bending moment $M_{Y^{0}}$ and torsional moment $T_{x^{0}}$ at an arbitrary section $\phi$ will be reduced to;

$$
\left.\begin{array}{l}
M_{Y^{0}}=M_{0} \cos (\phi-\Phi / 2) / \cos \Phi / 2 \\
T_{x^{0}}=M_{0} \sin (\phi-\Phi / 2) / \cos \Phi / 2
\end{array}\right\}
$$

Moreover, the warping moment $M_{\omega}{ }^{0}$ can be given by solving the following equation;

$$
\frac{d^{2} M_{\omega^{0}}}{d s^{2}}-\frac{G K}{E I_{\omega}} M_{\omega^{0}}=-\frac{M_{0}}{R_{0}}
$$

The deflection angles $\varphi_{y}$ and $\varphi_{z}$ due to bending can also be found by

$$
\varphi_{y}=-d w / d s, \quad \varphi_{z}=d v / d s+u / R_{s} \cdots \cdots \cdots \cdots(7)_{\mathrm{a}, \mathrm{b}}
$$

Accordingly, substitution of Eqs. (2) (7) into Eq. (1) gives a set of the simultaneous differential equations for the lateral buckling displacements $u, v, w, \beta$ and $\theta$ as follows;

$$
\begin{gathered}
E I_{y}\left(\frac{d^{4} w}{d s^{4}}-\frac{1}{R_{s}} \frac{d^{2} \beta}{d s^{2}}\right)-\frac{d^{2}}{d s^{2}}\left\{T_{x^{0}}\left(\frac{d v}{d s}+\frac{u}{R_{s}}\right)\right\} \\
-\frac{d^{2}}{d s^{2}}\left(M_{Y^{0} \beta+T^{0}} \frac{d w}{d s}\right) \frac{I_{Y Z}}{I_{Z}}=0 \\
E I_{z}\left\{\frac{R_{s}}{R_{0}}\left(\frac{d^{4} v}{d s^{4}}+\frac{1}{R_{s}^{2}} \frac{d^{2} v}{d s^{2}}\right)+\frac{z_{s}}{R_{0}}\left(\frac{d^{4} w}{d s^{4}}\right.\right. \\
\left.\left.\quad-\frac{1}{R_{s}} \frac{d^{2} \beta}{d s^{2}}\right)\right\}+\frac{d^{2}}{d s^{2}}\left(M_{Y^{0}} \beta+T_{x^{0}} \frac{d w}{d s}\right) \\
\quad+\frac{d^{2}}{d s^{2}}\left(T_{x^{0}} \varphi_{z}\right) \frac{I_{Y Z}}{I_{Y}}=0 \\
E I_{\omega} \frac{d^{4} \theta}{d s^{4}}-\overline{G K} \frac{d^{2} \theta}{d s^{2}}+\frac{d}{d s}\left\{M^{0}\left(\frac{d v}{d s}+\frac{u}{R_{s}}\right)\right\}=0
\end{gathered}
$$

where

$$
u=\int_{0}^{s} v / R_{s} d s+u_{0}
$$

$u_{0}$ : axial displacement at the origin $s=0$ and the symbols $I_{y}$ and $I_{z}$ are defined by

$$
\left.\begin{array}{l}
I_{y}=R_{s} / R_{0} \cdot\left(I_{Y}-I_{Y Z^{2}} / I_{Z}\right) \\
I_{z}=R_{s} / R_{0} \cdot\left(I_{Z}-I_{Y Z^{2}} / I_{Y}\right)
\end{array}\right\}
$$

The boundary conditions for displacements and stress-resultants can be put as

$$
v=w=\beta=\varphi_{z}=T_{s}=0, \quad M_{Y}=M_{0}
$$




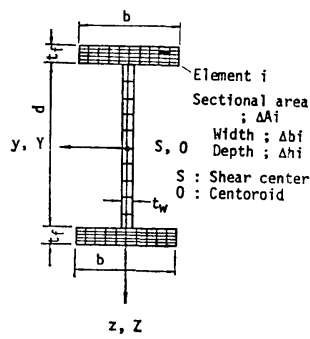

Fig. 17 Segmental method of cross section.

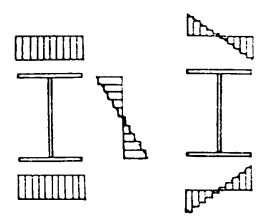

(a) Bending strain $\epsilon_{b}$ (b) Warping stra

Fig. 18 Strain distribution in I-girder.

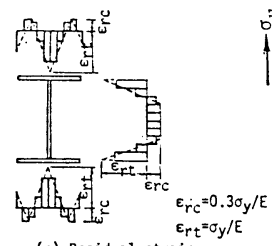

$\varepsilon_{r}$

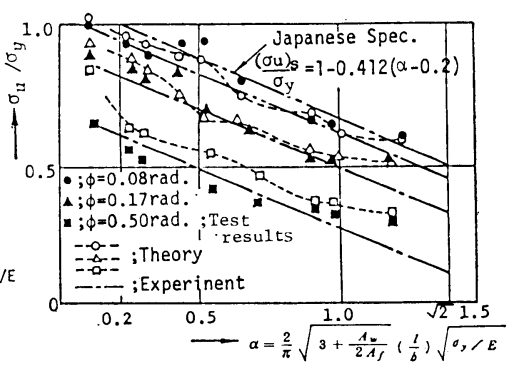

Fig. 19 Lateral buckling strength $\sigma_{u}$. for both the ends $\phi=0$ and $\phi=\Phi$ of girder, and

$$
u=0, \quad N_{X}=0
$$

for $\phi=0$ and $\phi=\Phi$ of girder, respectively.

By the way, these equations coincide perfectly with the results by references 18 ) 23); provided that the girder is a straight one $R_{s}=\infty$ having a symmetrical cross-section.

For the analyses of the material non-linearity, a cross-section of girder is divided into the small elements as shown in Fig. 17, and the following assumptions are set to estimate the elasto-plastic behaviours for each element;

1. The material obeys the completely elastoplastic behaviours.

2. Bernoulli-Euler's hypothesis can be applied to both bending strain $\varepsilon_{b}\left(=M_{Y}{ }^{0} / E I_{Y} \cdot Z\right)$ and warping strain $\varepsilon_{\omega}\left(=M_{\omega}{ }^{0} / E I_{\omega} \cdot \omega\right)$ as illustrated in Fig. 18 (a) and (b), respectively.

3. The residual stress $\sigma_{r}$ distributions are such a pattern as shown in Fig. 18 (c), in which residual strain means $\varepsilon_{r}=\sigma_{r} / E$.

4. The stiffness of element vanishes when the sum of strain $\varepsilon_{b}, \varepsilon_{\omega}$ and $\varepsilon_{r}$ exceed the yield strain $\varepsilon_{y}\left(=\sigma_{y} / E\right)$ of materials.

Thus, Eq. (8) can successively be solved by determining the rigidities $E I_{y}, E I_{z}, E I_{y z}$ and $E I_{\omega}$ on the basis of the above assumptions by regarding this problem as an eigen-value problem.

\section{(2) Comparison with test results}

The numerical calculations were conducted to the test girders IG-1 through IG-27. These results are summarized as shown in Table 2 together with the experimental ones.

Observing this table, it seems that the theoretical values coincide well with the experimental ones $(90 \% \sim 110 \%)$ for the case where the central angle $\Phi$ of girder is less than $0.2 \mathrm{rad}$.

\section{LATERAL BUCKLING STRENGTH OF CURVED I-GIRDER}

\section{(1) Lateral buckling strength}

The lateral buckling stress $\sigma_{u}$ of a curved Igirder can be obtained by dividing the ultimate moment $M_{u}$ by the corresponding section modulus $W_{y}$ as follows;

$$
\sigma_{u}=M_{u} / W_{y}
$$

To simplify the expression for $\sigma_{u}$, let us now arrange $\sigma_{u}$ by means of the following buckling parameter $\alpha$ which is defined by the Japanese Specification for Highway Bridges ${ }^{3)}$;

$$
\alpha=2 / \pi \cdot \sqrt{3+A_{w} /\left(2 A_{c}\right)} \cdot(l / b) \sqrt{\sigma_{y} / E}
$$

in which

$A_{c}$; area of compression flange

$A_{w}$; area of web plate

$b$; width of compression flange

and the effective buckling length $l$ can be written by;

$$
l=\lambda L
$$

where $L\left(=R_{s} \Phi\right)$ is the span length of curved Igirder, and the coefficient $\lambda$ can approximately be put as

$$
\lambda=0.492\left\{1+0.035 \Phi(L / b)^{1 / 3}\right\}
$$

through the parametric studies on the basis of elastic lateral buckling analysis ${ }^{5}$.

Fig. 19 shows the relationships between $\sigma_{u} / \sigma_{y}$, $\alpha$ and $\Phi$. The buckling stress $\sigma_{u}$ is entirely depended upon the buckling parameter $\alpha$ and the central angle $\Phi$ of curved I-girder.

\section{(2) Proposition of allowable bending com- pressive stress for curved I-girder}

The allowable bending compressive stress $\left(\sigma_{b a}\right)_{c}$ can be obtained by dividing the lateral buckling stress by the safety factor $\nu$ as follows;

$$
\left(\sigma_{b a}\right)_{c}=\sigma_{u} / \nu
$$

In order to express this stress by that of a straight I-girder $\left(\sigma_{b a}\right)_{s}$, the reduction factor $\psi_{1}(\alpha, \Phi)$, which is the function of buckling parameter $\alpha$ and central angle $\Phi$ of curved I-girder, must be multiplied by $\left(\sigma_{b a}\right)_{s}$, thus

$$
\left(\sigma_{b a}\right)_{c}=\psi_{1}\left(\sigma_{b a}\right)_{s}
$$

This reduction factor $\psi_{1}(\alpha, \Phi)$ can be plotted as shown in Fig. 20, and can approximately be given by the following formula through the least square method within the ranges $0.1 \leq$ $\alpha \leq \sqrt{2}$ and $\Phi \leq 0.2^{5}$. 


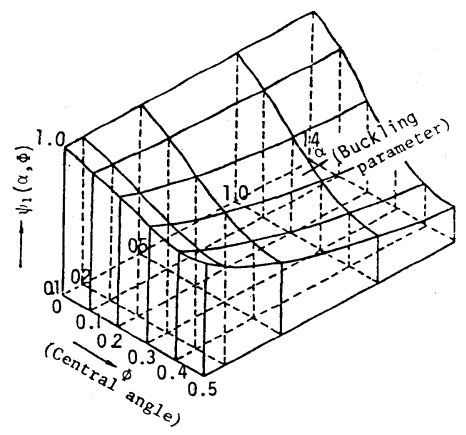

Fig. 20 Variations of $\psi_{1}(\alpha, \Phi)$.

$$
\psi_{1}=1-1.05 \sqrt{\alpha}\left(\Phi+4.52 \Phi^{2}\right)
$$

\section{APPLICATION TO DESIGN OF MULTIPLE CURVED I-GIRDER BRIDGES}

(1) Stress in main girders ${ }^{26}$

The stress bending in each main girder of a multiple curved I-girder bridge is given by

$$
\sigma_{b}=M_{y} / I_{y} \cdot z
$$

On the other hand, the additional warping stress $\sigma_{\omega}$ due to the out-of-plane bending of flange plates can be estimated by referring Fig. 21 (a) $\sim$ (c) as follows;

$$
\sigma_{\omega}= \pm k \sigma_{b} /\left(R W_{f}\right) \cdot\left(A_{f}+A_{s} / 3\right) L^{2}
$$

provided that the rigid supports are assumed at the junction points of floor beams or sway and lateral bracings, and where

$A_{\text {f }}$; cross-sectional area of flange plate, $A_{s}$; cross-sectional area of web plate from flange to neutral axis, $L$; longitudinal spacing of floor beams or sway and lateral bracings, $R$; radius of curvature of main girder, $W_{\Im}$; section modulus of flange plate $\left(=t_{f} b_{f}^{2} / 6\right.$, and $t_{f}$; flange thickness, $b_{f}$; flange width), $k$; bending moment coefficient as a continuous beam and can approximately be used $k=0.106$ as the maximum value.

\section{(2) Check for stress and lateral buckling strength}

The total compressive stresses at the compression flange of main girders should be satisfied the following criteria as defined by the specification;

$$
\left.\begin{array}{ll}
\sigma_{b c}+\sigma_{\omega c} \leq \sigma_{b a 0} ; & \text { for stress check } \\
\sigma_{b c} \leq\left(\sigma_{b a}\right)_{c} \quad ; \text { for buckling check }
\end{array}\right\}
$$

where

$\sigma_{b c}$; bending compressive stress, $\sigma_{\omega c}$; additional warping compressive stress, $\sigma_{b a 0}$; upper limit of allowable compressive stress $\left(\sigma_{b a}\right)_{c}$; allowable compressive stress for lateral buckling.

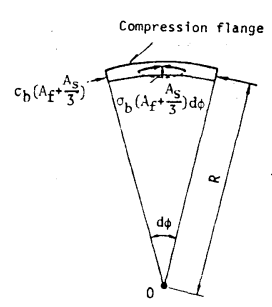

(a) Out-of-plane bending
of conpression flange

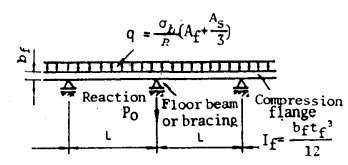

(b) Equivalent mode1

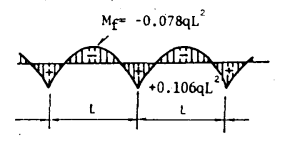

(c) Additional bending moment
Fig. 21 Additional warping stress $\sigma_{\omega}$.

It is, however, inconvenient for the practical use of simultaneous equations $(21)_{\mathrm{a}, \mathrm{b}}$. Then, dividing both sides of Eq. $(21)_{\mathrm{a}}$ by $\sigma_{b a_{0}}$ and approximating the denominator of first term of left hand-side of this equation with $\left(\sigma_{b a}\right)_{c}$, a simplified interaction formula can be obtained as follows;

$$
\frac{\sigma_{b c}}{\left(\sigma_{b a}\right) c}+\frac{\sigma_{\omega c}}{\sigma_{b a 0}} \leq 1.0
$$

i.e. Eq. $(21)_{\mathrm{b}}$ can entirely be fulfilled when $\sigma_{\omega c}=0$, and gives safety side when $\sigma_{\omega c}=0$.

Fig. 22 shows the interaction curves for $\sigma_{b c}$ $\sigma_{b a 0}$ vs. $\sigma_{\omega c} / \sigma_{b a 0}$ and $\left(\sigma_{b a}\right)_{c} / \sigma_{b a 0}$ vs. $\sigma_{\omega c} / \sigma_{b a 0}$, respectively.

Note that the buckling modes of curved Igirders between the supported portions by the floor beams or sway and lateral bracings have the same modes as the straight I-girder, when the central angle $\Phi$ is sufficiently small. This condition has been inquired from various parametric analyses, which gives $\Phi \leq 0.02 \alpha$. For these curved girders, the criterion relative to the straight girder can be applied to that of the curved girder by putting $\lambda=1$.

For the composite girder, the stress check can be conducted by Eq. (21) a alone. Moreover, the stress check for the tension flange can, of course, be conducted by;

$$
\sigma_{b t}+\sigma_{\omega t} \leq \sigma_{t a}
$$

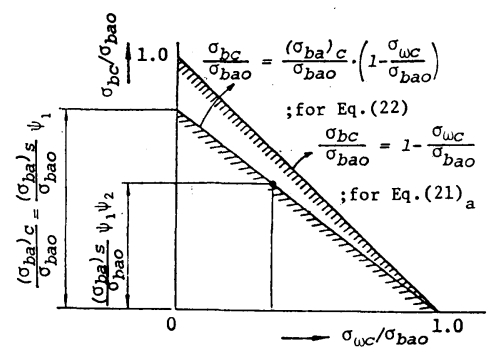

Fig. 22 Interaction curves for compression flange due to bending and additional warping stresses. 
Now, Eq. (22) can be rewritten as follows;

$$
\sigma_{b c} \leq\left(\sigma_{b a}\right) c\left(1-\sigma_{\omega c} / \sigma_{b a 0}\right)
$$

Then, substitution of Eq. (17) into the above equation gives

$$
\sigma_{b c} \leq\left(\sigma_{b a}\right) s \psi_{1} \psi_{2}
$$

where

$$
\psi_{2}=1-\sigma_{\omega c} / \sigma_{b a 0}=1-\left(\sigma_{b c} / \sigma_{b a 0}\right) \cdot\left(\sigma_{\omega c} / \sigma_{b c}\right)
$$

This equation is similar to a recommendation to AASHTO specification ${ }^{27}$.

\section{DESIGN METHOD OF FLOOR BEAMS, SWAY AND LATERAL BRACINGS FOR MULTIPLE CURVED I-GIRDER BRIDGES}

The multiple curved girder bridges, which are stiffened by the floor beams or sway and lateral bracings, always undergo the additional stresses due to the curvature of a bridge axis. These stresses are thought to be the primary ones rather than the secondary stresses in the straight girder bridges, then the floor beams or sway and lateral bracings should be designed so as to have enough strength and rigidities as the following manners in which informations are derived from the references 2 ) and 26) $\sim 31$ ).

\section{(1) Floor beams or sway bracings}

The necessary rigidity for the floor beams or sway bracings will be estimated by a condition given by the grillage theory as follows ${ }^{31}$;

$$
z=(l / 2 a)^{3} \cdot\left(I_{Q} / I\right) \geq 10
$$

where $l$; span length of multiple curved I-girder bridge, $a$; spacing of main girder, $I, I_{Q}$; moment of inertia of main girder and floor beam or sway bracing, respectively.

According to a recommendation for AASHTO specification $^{27}$, the adequate spacing of floor beams or sway bracings can be determined in connection with the radius of curvature $R$ of the multiple curved I-girder bridge.

\section{(2) Lateral bracings ${ }^{2)}$}

The lateral bracings should be attached to the upper and lower side of the flanges of the multiple curved I-girder bridges in order to decrease the additional stresses in the flange plates and to have the stability against overall lateral buckling of bridges during the erection $^{28) ~ 29)}$.

The strength of lateral bracing against horizontal forces such as wind or seismic loads should not only be taken into consideration, but also the following check must be performed for the multiple curved I-girder bridges. a) Additional stress due to out-of-plane bending of flange plates

The following reaction $P_{0}$ will be applied to the lateral bracings at the junction points of the main girders as already shown in Fig. 21 (b).

$$
P_{0}=\frac{\sigma_{b}\left(A_{s}+A_{s} / 3\right)}{R} \cdot \frac{l_{1}+l_{2}}{2}
$$

where $l_{1}, l_{2}$; spacing of lateral bracing as shown in Fig. 23 .

The resulting stresses caused by this reaction $P_{0}$ can easily be found by referring Fig. 23 as follows;

$$
\left.\begin{array}{l}
\sigma_{1}=P_{0} / A_{1} \cdot \sin \theta_{2} / \sin \left(\theta_{1}+\theta_{2}\right) \\
\sigma_{2}=P_{0} / A_{2} \cdot \sin \theta_{1} / \sin \left(\theta_{1}+\theta_{2}\right)
\end{array}\right\}
$$

where

$\begin{aligned} & \sigma_{1}, \sigma_{2} ; \begin{array}{l}\text { normal } \\ \text { stress }\end{array} \\ & A_{1}, A_{2}: \begin{array}{l}\text { cross-sectional } \\ \text { area }\end{array} \\ & \theta_{1}, \theta_{2} ; \text { inclination } \\ & \text { angle }\end{aligned}$

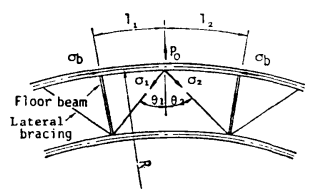

Fig. 23 Stress caused by out-of-plane bending of flange plate. b) Additional stress due to torsion

The multiple curved I-girder bridges are always subjected to the torsional moment. The stress due to torsion can approximately be evaluated by the following simplified method. First, let a multiple curved girder bridge be idealized as a quasi-box bridge ${ }^{30)}$. The equivalent thickness $t_{r}$ of top or bottom plates of those box girder bridge can be reduced as follows;

$$
t_{r}=\frac{E}{G} \cdot \frac{a l}{\left(d^{3} / A_{d}+2 l^{3} / 3 A_{f}\right)}
$$

where $A_{a}$; cross-sectional area of lateral bracing, $A_{\jmath}$; cross-sectional area of flange plate, $a$; spacing of main girder, $d$; length of lateral bracing, $l$; spacing of lateral bracing, E; Young's modulus, $G$; shear modulus of elasticity (see Fig. 26).

Fig. 24 illustrates the corresponding quasibox girder bridges.

Next, the shear flow $q$ due to the torsional moment $T$ can be estimated by Bredt's formula as follows;

$$
q=T / 2 F
$$

where the torsional moment can approximately

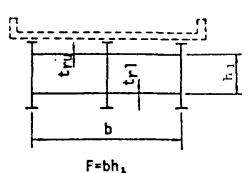

(a) Non-composite girder

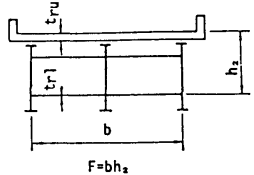

(b) Composite girder
Fig. 24 Quasi-box girder bridges. 
Table 3 Torsional moment T.

\begin{tabular}{|c|c|c|c|}
\hline Loads & Loading position & Formulae for torsional moment & Interporation at intermediate span \\
\hline \multirow[t]{2}{*}{ Dead load } & Edge-span & $T_{d l}=W_{d} R^{2}\left(\begin{array}{cc}1-\cos \phi-\phi \\
\sin \phi\end{array}-\frac{2}{2}\right)$ & $\begin{array}{l}\text { life curve } \\
2=0\end{array}$ \\
\hline & Mid-span & $T_{d 2}=0$ & 12 \\
\hline \multirow[b]{2}{*}{ Live load } & $\left.\right|_{-1} ^{p_{l} q_{l}}$ & $T_{l 1}=P_{l}\left(R_{p}-R\right)+q_{l} R_{p}\left(R_{p} \begin{array}{c}1-\cos \phi \\
\sin \phi\end{array}-\begin{array}{c}R \phi \\
2\end{array}\right)$ & \multirow{2}{*}{ 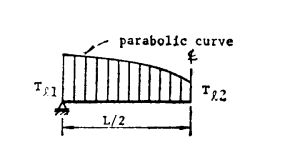 } \\
\hline & 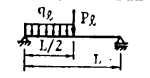 & 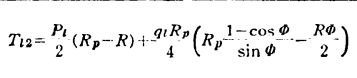 & \\
\hline
\end{tabular}

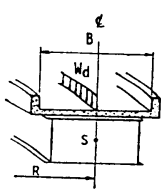

(a) Dead load

Fig. 25 Loading conditions.

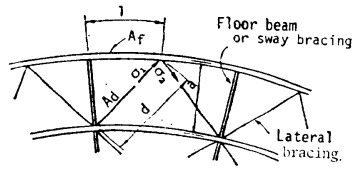

Fig. 26 Additional stress caused by torsion.

be determined by Table 3 corresponding to the loading conditions as shown in Fig. 252).

Finally, hence the force acts on the lateral bracing with the length $d$ is

$$
Q=q d
$$

the normal stresses due to torsion can be estimated by

$$
\left.\begin{array}{rl}
\sigma_{1}=-Q / A_{1} ; & \text { compression } \\
\sigma_{2}=Q / A_{2} ; & \text { tension }
\end{array}\right\}
$$

and plotted as shown in Fig. 26.

\section{CONCLUSION}

This paper deals with the lateral buckling strength and corresponding rational design method of the horizontally curved I-girder bridges.

Through the experimental studies on multiple curved I-girder models, it is shown that the overall lateral buckling is not so important phenomenon that the local buckling of main girder between the supported portions by floor beams or sway and lateral bracings should be taken into accounts for designing the curved I-girder bridges.

Accordingly, the local buckling tests of twenty seven model girders were carried out under the loading conditions of approximately pure bending. Then, numerous data could be obtained to estimate the buckling strength of curved Igirder.

On the other hand, the analytical method to evaluate the lateral buckling strength of curved I-girders was discussed in connection with the experimental data. The fundamental equation by using the second order analysis can be derived by taking into consideration both the geometrical and material non-linearities. It seems that the theoretical values coincide well with the experimental ones in the case where the central angle of girder is $\Phi \leq 0.2 \mathrm{rad}$.

Then, the ultimate strength for lateral buckling was investigated through the buckling parameter $\alpha$ and the central angle $\Phi$ of curved I-girder. And, the applications of these results to the design of multiple curved I-girder bridges can be shown in detail, and a simplified interaction curve can be proposed, which is the similar form as a recommendation for AASHTO specification.

Finally, the design methods of floor beams or sway and lateral bracings to prevent the overall lateral buckling and to have enough strength and rigidities against additional stresses due to out-of-plane bending of flange plate and torsional moment can concretely be indicated in this paper.

\section{ACKNOWLEDGEMENTS}

The authors heartly wish to acknowledge the valuable suggestions given by Prof. S. Komatsu of Osaka University. Our thanks are also due to; The Japanese Ministry of Education for Scientific Research Funds and the sponsorship by the Hanshin-Highway Public Corporation.

\section{REFERENCE}

1) The Task Committee on Curved Box Girders of the ASCE-AASHTO Committee of Metal of ASCE Structural Division: Curved Steel BoxGirder Bridge: A Survey, Proc. of ASCE, ST11, pp. 1697 1718, Nov., 1978.

2) The Hansin Highway Public Corporation: The Design Code, Part 2, Design codes for structure, April, 1980 (in Japanese).

3) The Japanese Road Association: The Japanese Specification for Highway Bridges, Feb., 1980.

4) Kotoguchi, H., H. Nakai and M. Kubo: Stiffening effects of sway and lateral bracings upon the ultimate strength of curved I-girder bridges, 33th Annual Conference of JSCE, pp. 131 132, Sept., 1978 (in Japanese).

5) Kotoguchi, H., M. Kubo and H. Nakai: Study on Geometric Non-linearity of Thin-Walled 
Horizontally Curved Beams and Application to Lateral Buckling Strength of Curved I-Beams, 24th Structural Symposium of Non-linear Problem for Structure, pp. 69 76, Feb., 1978 (in Japanese).

6) Love, A. E. H.: Mathematical Theory of Elasticity, 4th. ed., Cambridge Press, 1952.

7) Namita, Y.: Die Theorie II. Ordnung von Krummten Stäben und ihre Anwendung auf das Kipp-Problem des Bogenträgers, Trans. of JSCE, No. 155, s. 87 103, 1970.

8) Ojalvo, M., E. Demutu and F. Takarz: Outof-plane Buckling of Curved Members, Proc. of ASCE, Vol. 95, ST-11, pp. 2305 2316, Nov., 1969.

9) Tameroglu, S. and I. Turkey: Finite Theory of Thin Elastic Rods, Acta Mechanica, 11, pp. 271 282, 1971.

10) Schroeder, F. H.: Allegemine Stabtheorie des raumlich Vorgekrümungen und Vorgewunden Trägers mit Grossen Verformungen, Ing-Archiv. 39, s. $87 \sim 103,1970$.

11) Enda, Y.: Analysis of Thin-Walled Curved Beams with Open Cross Section as Finite Displacement Theory by Transfer Matrix Method, Proc. of JSCE, No. 199, pp. 11 20, May, 1972 (in Japanese).

12) Usuki, M., T. Kano and N. Watanabe: Analysis of Thin Walled Curved Members in Account for Latge Torsion; Proc. of JSCE, No. 290, pp. $1 \sim 12$, Oct., 1979 (in Japanese).

13) Hirashima, M., M. Iura and T. Yada: Finite Displacement Theory of Naturally Curved and Twisted Thin-Walled Members, Proc. of JSCE, No. 292, pp. 13 25, Dec., 1979 (in Japanese).

14) Nakai, H., S. Muramatsu, N. Yoshikawa, T. Kitada and R. Ohminami: A Survey for Web Plates of the Horizontally Curved Girder Bridges, Bridge and Foundation, pp. 38 45, May, 1981.

15) Culver, C. G. and P. F. McManus: Instability of Horizontally Curved Members-Lateral Buckling of Curved Plate Girder, Carnegie-Mellon Univ. Report, Sept. 1971.

16) McManus, P. F.: Lateral Buckling of Curved Plate Girders, Ph. D. Disertation, Department of Civil Engineering, Canegie-Mellon University, 1971.

17) Fukumoto, Y. and S. Nishida: Ultimate Load Behavior of Curved I-Beams, Proc. of ASCE, Vol. 107, F.M-2, pp. 367 388, 1981.

18) Clark, J. W. and J. R. Jambock: Lateral Buckling of I-Beams Subjected to Unequal End Mo- ments, Proc. of ASCE, Vol. 83, EM-3, July, 1957.

19) Galambos, T. V.: Inelastic Buckling of Beams, Proc. of ASCE, Vol. 89, ST-5, Oct. 1963.

20) Column Research Council: Guide to Design Criteria for Metal Compression Members, John Wiley and Sons, New York, 1966.

21) Galambos, T. V.: Structural Members and Frames, Prentice Hall, Inc., 1968.

22) Structural Stability Research Council: Guide to Stability Design Criteria for Metal Structures, 3rd. Ed., John Wiley \& Sons, 1976.

23) Fukumoto, Y., M. Fujiwara and N. Watanabe: Inelastic Lateral Buckling Tests on Welded Beams and Girder, Proc. of JSCE, No. 189, pp. 39 51, May, 1971 (in Japanese).

24) Nakai, H., H. Kotoguchi and T. Tani: Matrix Structural Analysis of Thin-Walled Curved Girder Bridges Subject to Arbitrary Loads, Proc. of JSCE, No. 225, pp. $1 \sim 15$, Nov. 1976 (in Japanese).

25) Maegawa, $K$. and $H$. Yoshida: Ultimate Strength Analysis of Curved I-Beams by Transfer Matrix Method, Proc. of JSCE, No. 312, pp. 27 42, Aug., 1981 (in Japanese).

26) Nakai, H. and C. P. Heins: Analysis Criterion for Curved Bridges, Proc. of ASCE, ST-7, pp. 1419 1427, July, 1977.

27) The Task Committee on Curved Girders of the ASCE-AASHTO Committee on Flexual Member of the Committee on Metals of Structural Division: Curved I-Girder Bridge Design Recommendations, Proc. of ASCE, Vol. 103, ST-5, pp. 1137 1167, May, 1977.

28) Otsuka, H. and T. Yoshimura: Studies on Additional Stresses of Main Girders and Member Forces of Lateral Bracing in Curved $I$ and Straight I-Girder Bridges, Proc. of JSCE, No. 290, pp. 17 29, Oct., 1979 (in Japanese).

29) Otsuka, H., T. Yoshimura, H. Hikosaka and K. Hirata: Analysis of Curved Girder Bridges Considering Eccentric Connection Between a Deck Plate and Girders, Proc. of JSCE, No. 259, pp. $11 \sim 23$, May, 1977 (in Japanese).

30) Heins, C. P.: Bending and Torsional Design in Structural Members, Lexington Book, 1975.

31) Komatsu, S., H. Nakai and Y. Taido: A proposition for Designing the Horizontal Curved Bridges in Connection with Ratio between Torsional and Flexural Rigidities, Proc. of JSCE, No. 224, pp. 55 66, Apr., 1974 (in Japanese).

(Received December 20, 1982) 
土木学会論文報告集 第 339 号

\section{曲線 I 桁橋の横倒れ座屈強度と 設計法に関する研究}

（中井 博／事口寿男）
となった。

したがって，次に曲率半径，スパソ，および道路橋示 方書で与えられている座屈パラメーター $\alpha$ が種々異な る 27 体の I 形模型による横倒れ座屈実験を，実橋をモ デルにした境界条件を用いて行った. その結果, 曲線 I 形ばりの中心角と座屈パラメーター $\alpha$ が大になれば，横 倒れ座屈強度は低下することが明らかとなった。

一方, 材料, および幾何学的非線形性を考慮した 2 次 理論によって曲線 I 形ばりの横倒れ座屈強度を数值計算 した. 曲線 I 形ばりの中心角が $0.2 \mathrm{rad}$ 以内では実験值 と理論值との比は $90 \%$ 110\%にあり，両者はよく一致 した.

これらの実験值, および理論值より, まず並列曲線 I 桁橋の固定間距離内における主桁の有効座屈長の算定式 を示し, 曲線 I 形ばりの横倒れ座屈強度式を中心角 $\Phi$ と 座屈パラメーター $\alpha$ によて整理した，さらに，並列曲 線 I 桁橋の主桁設計への適用に際し，簡単な相関曲線に よって, 横倒れ座屈を考慮した応力照査式を提示した.

並列曲線 I 桁橋では, 通常, 荷重分配作用の増大と橋 全体のねじり剛性を高めるために十分な剛性を有する横 桁, あるいは対傾構, および横構を配置しなければなら ない.したがって, これらの横桁, あるいは対傾構, お よび横構を合理的に設計するための指針を与えた。すな わち, 横桁, あるいは対傾構に対し, その必要剛度の算 定式を示した。また，風荷重や地震荷重以外で，曲率の 影響によるフランジに作用する面外方向応力とねじり モーメントによって生じる横構部材応力の算定法を示し た。 